\title{
Structural Fe(II) Oxidation in Biotite by an Ectomycorrhizal Fungi Drives Mechanical Forcing
}

\author{
Steeve Bonneville, ${ }^{* \dagger}$ Andrew W. Bray, ${ }^{\ddagger}$ and Liane G. Benning ${ }^{\ddagger} \S$ \\ ${ }^{\dagger}$ Biogéochimie et Modélisation du Système Terre, Département Géosciences, Environnement et Société, Université Libre de \\ Bruxelles, 50 av. F. D. Roosevelt, 1050 Brussels, Belgium \\ ${ }^{\ddagger}$ Cohen Geochemistry, School of Earth and Environment, University of Leeds, Leeds LS2 9JT, United Kingdom \\ ${ }^{\S}$ GFZ, German Research Centre for Geosciences, Telegrafenberg, Potsdam 14473, Germany
}

\section{Supporting Information}

ABSTRACT: Microorganisms are essential agents of Earth's soil weathering engine who help transform primary rock-forming minerals into soils. Mycorrhizal fungi, with their vast filamentous networks in symbiosis with the roots of most plants can alter a large number of minerals via local acidification, targeted excretion of ligands, submicron-scale biomechanical forcing, and mobilization of $\mathrm{Mg}, \mathrm{Fe}, \mathrm{Al}$, and $\mathrm{K}$ at the hypha-biotite interface. Here, we present experimental evidence that Paxillus involutus-a basidiomycete fungus-in ectomycorrhizal symbiosis with Scots pine (Pinus sylvestris), is able to oxidize a substantial amount of structural $\mathrm{Fe}(\mathrm{II})$ in biotite. Iron redox chemistry, quantified by X-ray absorption near edge spectra on 13 fungi-biotite sections along three

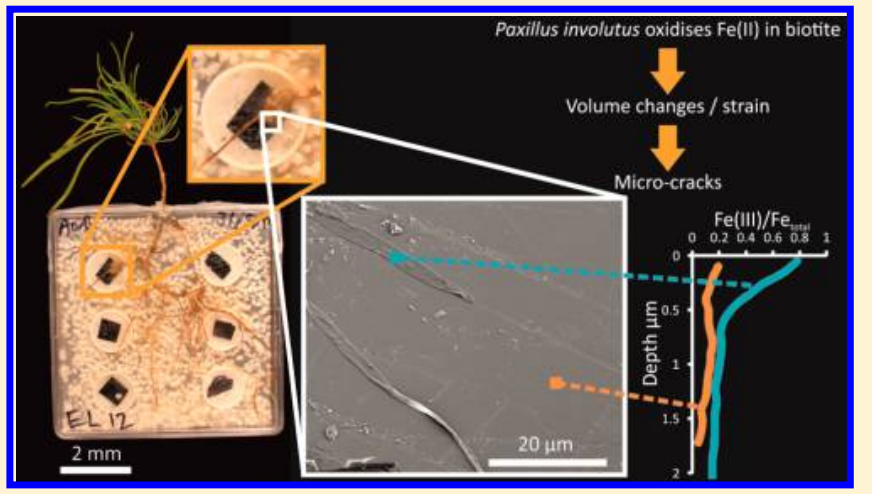
distinct hypha colonizing the [001] basal plane of biotite, revealed variable but extensive $\mathrm{Fe}$ (II) oxidation up to $\sim 2 \mu \mathrm{m}$ in depth and a $\mathrm{Fe}(\mathrm{III}) / \mathrm{Fe}_{\text {total }}$ ratio of up to $\sim 0.8$. The growth of $\mathrm{Fe}(\mathrm{III})$ hydroxide implies a volumetric change and a strain within the biotite lattice potentially large enough to induce microcrack formation, which are abundant below the hypha-biotite interface. This $\mathrm{Fe}$ (II) oxidation also leads to the formation of a large pool of $\mathrm{Fe}$ (III) (i.e., structural Fe(III) and Fe(III) oxyhydroxides) within biotite that could participate in the Fe redox cycling in soils.

\section{INTRODUCTION}

Fungi represent a substantial portion of the Earth's biosphere. In soils, they play a significant role in the weathering of primary rock-forming minerals into secondary clay minerals. ${ }^{1}$ The symbiosis (i.e., mycorrhiza) that fungi can form with the root system of most plants-80\% of land plant species ${ }^{2,3}$-is sustained by a substantial fraction (up to 30\%) of net photosynthesis. ${ }^{4}$ This energy supply from the host plant sustains a massive network of microscopic filaments-hyphawhich can reach $200 \mathrm{~m}$ cumulative length per gram of soil, a much larger interfacial reactive surface with the soil environment than plant rootlets. ${ }^{4} \mathrm{~A}$ series of recent experimental studies have pushed the notion that the fungal biomass can enhance weathering of rocks or minerals commonly found in soils. These include biotite, ${ }^{5}$ chlorite, ${ }^{6}$ apatite, ${ }^{7}$ and rocks such as limestone, basalt, and gabbro; ${ }^{8}$ however, this has been questioned for apatite in a field study. ${ }^{9}$

Two of the most common rocks, granite and basalt, that represent the bulk of the continental and oceanic crusts, are Fe rich. Most of the $\mathrm{Fe}$ contained in their constitutive primary minerals, including biotite, is in the ferrous form, $\mathrm{Fe}(\mathrm{II})$. When exposed to the oxidative conditions at the Earth's surface, this structural $\mathrm{Fe}$ (II) tends to oxidize and due to their low solubility readily precipitate as various, most often poorly ordered $\mathrm{Fe}$ (III) oxyhydroxides. Biotite belongs to the Fe(II)-rich phyllosilicates within the mica group and forms a solid-solution series between an iron-end member, annite, and the magnesium-rich phlogopite. As one of the three main constituents of granite, biotite is widespread at the Earth' surface where it represents $\sim 7 \%$ of the exposed continental crust. ${ }^{10}$ Experiments of biotite weathering in aqueous solution, ${ }^{11,12}$ in the presence of bacteria, ${ }^{13}$ in interaction with fungi alone ${ }^{14}$ or in symbiotic association with plant roots ${ }^{5,15}$ have all shown that this mineral can be a source of $\mathrm{K}, \mathrm{Mg}, \mathrm{Al}$, and $\mathrm{Fe}$ which are potentially bioavailable for soil biota. The abiotic aqueous weathering sequence of biotite, is dominated in the first stages by the release of interfoliar $\mathrm{K}^{16,17}$ This triggers its transformation toward vermiculite, while the structural Fe(II), mainly in the octahedral sheets, is oxidized into $\mathrm{Fe}(\mathrm{III}){ }^{18}$

Soil biota have the potential to enhance biotite weathering. Roots, bacteria, and fungi can indeed modify the chemical composition and lower the $\mathrm{pH}$ of fluids in their nearenvironment through (i) the exudation of protons to balance

Received: December 17, 2015

Revised: April 11, 2016

Accepted: April 29, 2016

Published: April 29, 2016 


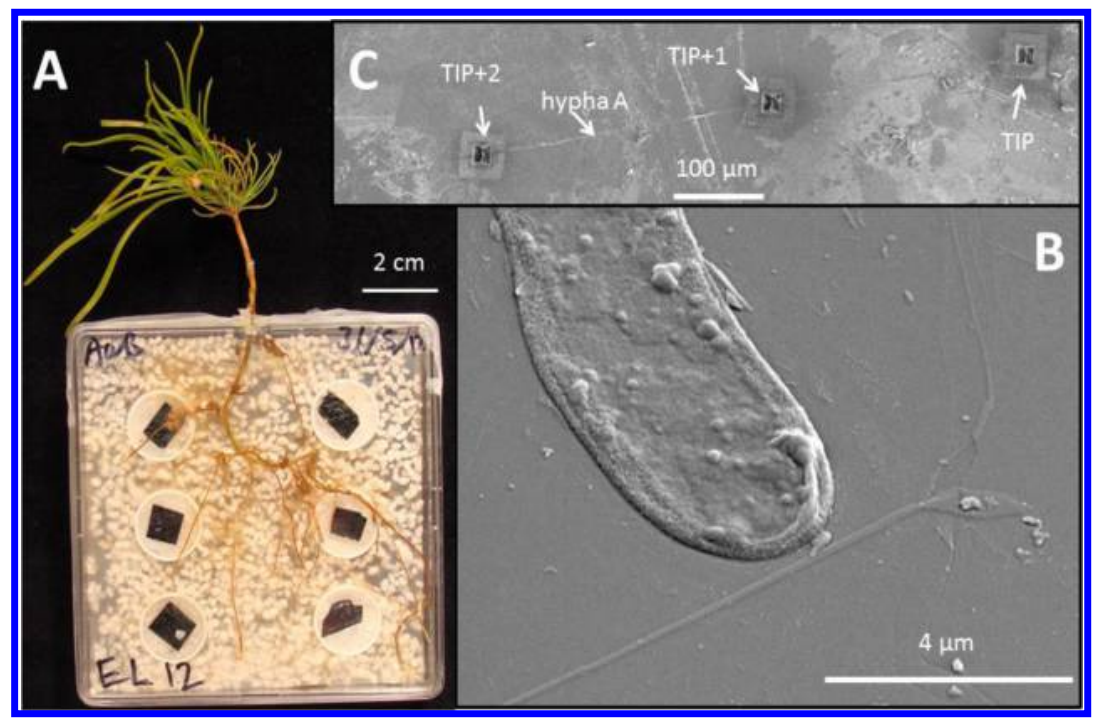

Figure 1. (A) Experimental microcosm after 4 months of growth. The mycelium that colonizes the biotite flakes appears as an orange haze around roots. (B) SEM micrographs of the tip of hypha "A" before FIB milling, respectively. (C) SEM micrographs of hypha A sampled and of the three FIB sections.

for uptake of cations ${ }^{19}$ and/or the (ii) production of ligands and $\mathrm{CO}_{2}$-producing dissimilatory reactions. ${ }^{20}$ All of these biological processes will enhance mineral dissolution reactions beyond the abiotic levels in the near-environments of active microorganisms. ${ }^{5,8,21}$ Bacteria have also been shown to affect the Fe redox state within biotite. For example, nitrate-reducing bacteria can oxidize up to $\sim 5 \%$ of the total structural $\mathrm{Fe}$ (II) of biotite. $^{22}$ Similarly, Shewanella putrefaciens-a well-known $\mathrm{Fe}(\mathrm{III})$ reducing bacteria ${ }^{23}$ - can reduce up to $36 \%$ of the initial $\mathrm{Fe}$ (III), which can account in itself for up to $20 \%$ of the total $\mathrm{Fe}$ in the biotite crystalline structure. ${ }^{24}$ Early studies have also demonstrated the capacity of some fungi species- mostly the nitrate-reductase inducible taxa- to reduce $\mathrm{Fe}(\mathrm{III})$ oxides. $^{25}$

However, very few studies focused on the oxidation potential of fungi toward $\mathrm{Fe}(\mathrm{II})$ or, for that matter, of any other redox sensitive elements in the crystalline structures of minerals. Although, several studies ${ }^{26-28}$ have qualitatively assessed the oxidation of $\mathrm{Fe}(\mathrm{II})$ in biotite in the presence of mycorrhiza, so far no quantification of the extent of such an $\mathrm{Fe}$ (II) oxidation or the localization of an oxidative front are available. This is despite the fact that $\mathrm{Fe}$ oxidation reactions often initiate mineral weathering, i.e., when primary minerals interact first with oxygenated fluids iron is one of the first and fastest reacting redox element often leading to the formation of poorly soluble $\mathrm{Fe}$ (III) oxyhydroxyde. Interestingly, the formation of secondary $\mathrm{Fe}$ (III) phases due to the oxidation of $\mathrm{Fe}$ (II)-bearing minerals including biotite and pyroxenes was shown to also increase strain (due to volumetric changes) within mineral lattice structures, leading to microcrack formation. ${ }^{29-31}$ Ultimately in soils, this phenomenon increases porosity, allowing for water infiltration, which further favors and enhances subsequent mineral dissolution. What is, however, still unknown is what the role and effect of fungal colonization on the iron speciation in pristine $\mathrm{Fe}(\mathrm{II})$ rich minerals during weathering.

In this study, we measured the capacity of mycorrhizal fungi to oxidize structural $\mathrm{Fe}$ (II) in biotite that was colonized by fungal networks in plant-mycorrhiza-mineral continuum systems. We quantified submicron-scale changes in ferric to total iron $\left(\mathrm{Fe}(\mathrm{III}) / \mathrm{Fe}_{\text {total }}\right)$ speciation and complemented these measurements with assessments of changes in C-rich compounds at the interface between ectomycorrhizal hypha and the basal [001] plane of biotite. With this study, we do not only provide a first comprehensive and spatially resolved high resolution data set of fungal $\mathrm{Fe}(\mathrm{II})$ oxidation of a Fe-rich silicate minerals in close-to-natural conditions, but we also elucidate whether the presence of $\mathrm{Fe}(\mathrm{III})$ oxides subdomains can cause strain and mechanical forcing of the biotite crystalline structure, which in turn leads to further weathering.

\section{MATERIALS AND METHODS}

Microcosm Setup. Biotite mycorrhizal weathering experiments were carried out in monoxenic microcosms following the methods described in refs 5, 27, and 32 (Figure 1). Briefly, Paxillus involutus-an ectomycorrhizal fungi-and Pinus sylvestris-Scots pine-were initially grown separately, then both transferred into the same Petri dish to initiate symbiosis. Symbiotic pairs were subsequently transferred into experimental microcosms, where freshly cleaved biotite flakes $(\sim 0.5 \mathrm{~cm} \times$ $0.5 \mathrm{~cm}$ and $1 \mathrm{~mm}$ thick, positioned away from roots) were the main source of nutrients (i.e., $\mathrm{K}, \mathrm{Mg}, \mathrm{Fe}$ ) as illustrated in Figure 1A. Microcosms were incubated for $\sim 4$ months at 15 (days) and $10{ }^{\circ} \mathrm{C}$ (nights) with an $18 \mathrm{~h}$ photoperiod with a photon flux density of $550 \mu \mathrm{mol} \mathrm{m} \mathrm{m}^{-2} \mathrm{~s}^{-1}$ following the methods described previously. 5,27

Sampling of Hypha-Biotite Interface. Three biotite flakes colonized by mycelia connected to the plant roots however not in contact with the rootlets were collected from three different microcosms. The separated biotite-fungal samples were sectioned using a focus ion beam (FIB, dual beam FEI Nova 200 NanoLab) following the procedure described in Bonneville et al. (2009). ${ }^{27}$ In each sample, 3-4 sections were cut along single, isolated and continuous hypha (700 to $900 \mu \mathrm{m}$ long). Sections were cut starting in each case from the tip (Figure 1B) and progressing away from the tip (Figure 1C) to obtain a time sequence of exposure. On each biotite surface at least $\sim 100 \mu \mathrm{m}$ away from any hypha a control section was also cut. In total, 13 ultrathin FIB sections along three hyphae ("A", "B", and "C") starting from the fungal tip toward the older parts were prepared (Table S1). These FIB 


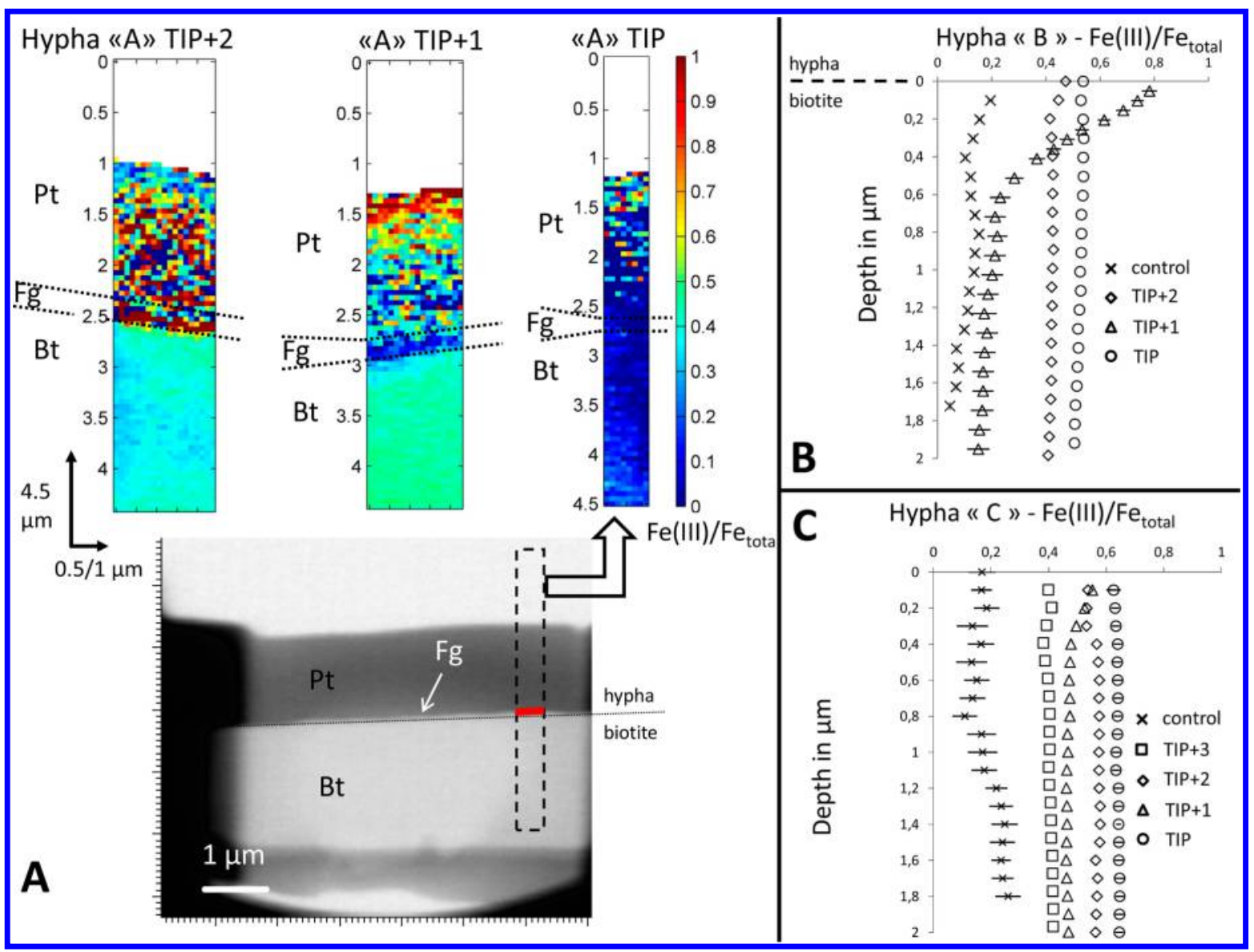

Figure 2. (A) $\mathrm{Fe}(\mathrm{III}) / \mathrm{Fe}_{\text {total }}$ ratio maps in the three FIB sections cut along hypha A with dashed lines highlighting the estimated position of the physical interfaces between fungi and biotite and between the fungi and the Pt deposit. (bottom) Red rectangle highlighting the position of hypha analyzed in the A TIP. (B and C) Depth profiles of $\mathrm{Fe}(\mathrm{III}) / \mathrm{Fe}_{\text {total }}$ in the topmost $2 \mu \mathrm{m}$ of biotite in contact with hypha or Pt deposit (controls) based on linescans $(695-730 \mathrm{eV})$ on the FIB sections sampled on hypha B and C. (O) TIP FIB section; $(\triangle)$ TIP +1 FIB section; $(\diamond)$ TIP +2 FIB section; ( $\square$ ) TIP + 3 FIB section (only for hypha C).

sections were subsequently imaged and analyzed using transmission electron microscopy (TEM) as described in Bonneville et al. ${ }^{27}$ and spectrally analyzed using scanning transmission X-ray microscopy (STXM).

Carbon, Potassium, and Ferrous/Ferric Iron Ratio Mapping. STXM mapping and collection of X-ray absorption near edge spectra (XANES) at the $\mathrm{Fe}_{2,3}$ edges (700-730 eV) and for both $\mathrm{C}$ K-edge and $\mathrm{K} \mathrm{L}_{2,3}$ edges (between 285 and 305 $\mathrm{eV}$ ) were performed on all 13 FIB sections either at the PolLux beamline (Swiss Light Source) or at beamline 5.3.2 at the Advanced Light Source (USA).

Monochromatic X-rays focused on the sample using a Fresnel zone plate were used to collect $2 \mathrm{D}$ images by scanning the sample stage at a fixed energy with a spot size of $\sim 40 \mathrm{~nm}$. Combining the images from each energy steps $(0.1 \mathrm{eV}$ in fine regions or $0.25 / 0.5 \mathrm{eV}$ in pre- or postedge) produced $3 \mathrm{D}$ image "stacks" of the differential absorption of X-rays of the FIB sections. XANES line-scans were also acquired across the hypha-biotite interface. Maps of $\mathrm{Fe}(\mathrm{III}) / \mathrm{Fe}_{\text {total }}$ ratios, as well as maps of potassium and of the various carbon functional groups were acquired and processed. ${ }^{33}$ To quantify the Fe speciation in linescans (with aXis 2000) and stacks (with Matlab routines), singular value decomposition was performed using $\mathrm{Fe}$ (II)siderite - and $\mathrm{Fe}(\mathrm{III})$ - goethite- as reference spectra. For C, the peak area at $285.4 \mathrm{eV}$ (due to the transition $\mathrm{C} 1 \mathrm{~s} \rightarrow \pi^{*}$ (* excited states) of the $\mathrm{sp}^{2}$ hybridized carbon (i.e., $\mathrm{C}=\mathrm{C}$ bonds), the peak at $288.5 \mathrm{eV}$ characteristic of the $\mathrm{C} 1 \mathrm{~s} \rightarrow \pi_{-\left(\mathrm{C}^{*}=\mathrm{O}\right) \mathrm{OH}}^{*}$ transition for $-\mathrm{COOH}$ groups ${ }^{33,34}$ were integrated (Figure $\mathrm{S}$ 1). Fe and C-related Matlab scripts are available online from refs 35 and 36, respectively. All STXM measurements were performed with dwell times of $<3.5 \mathrm{~ms}$ (per energy step per pixel), which was shown to induce negligible $\mathrm{Fe}(\mathrm{II})$ oxidation due to X-ray beam damage in chlorite, a phyllosilicate closely related to biotite. ${ }^{37}$

\section{RESULTS AND DISCUSSION}

Our data shows that at or close to the contact with ectomycorrhizal hypha, structural $\mathrm{Fe}(\mathrm{II})$ oxidation was extensive in the biotite. Control sections had an average $\mathrm{Fe}(\mathrm{III}) / \mathrm{Fe}_{\text {total }}$ ratio of $\sim 0.17 \pm 0.06 \mathrm{SD}(n=53)$ with values ranging from 0.04 to 0.26 (Figure S-2 for control FIB section corresponding to hypha A). These are in line with bulk Fe(III)/ $\mathrm{Fe}_{\text {total }}$ ratio of 0.175 reported for the Moen biotite. ${ }^{38}$ The measured ranges of $\mathrm{Fe}$ (III) $/ \mathrm{Fe}_{\text {total }}$ ratios highlights the inherent heterogeneous nature of the $\mathrm{Fe}$ valency within the biotite structure. Upon hypha colonization, the biotite $\mathrm{Fe}(\mathrm{III}) / \mathrm{Fe}_{\text {total }}$ ratios increases by a factor of 3 to 5 , reaching values up to $\sim 0.8$ under hypha B and A (near the interface with the hypha) and a value over 0.6 under hypha $C$ (Figure 2). Despite the fact that $\mathrm{Fe}(\mathrm{II})$ oxidation was observed underneath all three hypha, the data revealed that the evolution and extent of this redox change along each hypha was quite variable. For instance in hypha $\mathrm{A}$ 


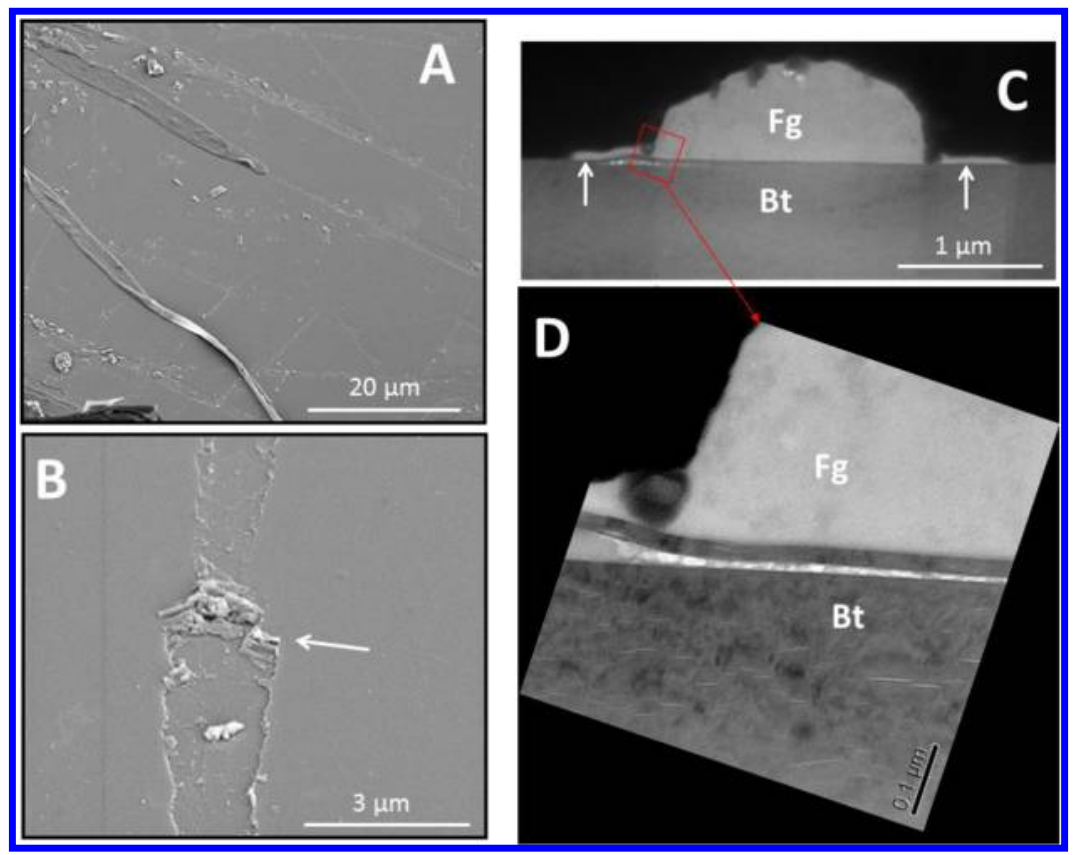

Figure 3. (A) SEM micrographs showing numerous channels (3-5 $\mu$ m width) on the basal plane of biotite with (B) illustrating that some of the topmost biotite material is pushed away in the probable direction of hyphal pulsatile growth. (C) TEM bright-field micrographs of a FIB hyphabiotite section (not analyzed by XANES) showing a large crack near the interface with the hypha as well as an extensive "biolayer" (arrows) expanding from the central hypha. (D) Exfoliated layer and numerous microcracks at depth in the biotite. Note that all control FIB sections were free of such macro- and microcracks (see previous work ${ }^{27}$ for detailed TEM observation of control sections).

(Figure $2 \mathrm{~A}$ ), $\mathrm{Fe}(\mathrm{III}) / \mathrm{Fe}_{\text {total }}$ maps showed a tip section underneath which, relative to the control section, little $\mathrm{Fe}$ (II) oxidation was observed $\left(\mathrm{Fe}(\mathrm{III}) / \mathrm{Fe}_{\text {total }}\right.$ ratios between 0.05 and 0.35 (Figure S-2). In contrary, the section located $\sim 300 \mu \mathrm{m}$ away from the tip (A TIP + 1) showed a larger Fe(II) oxidation with $\mathrm{Fe}(\mathrm{III}) / \mathrm{Fe}_{\text {total }}$ ratios of $\sim 0.4-0.6$. Interestingly, the A TIP +2 section-the furthest away from the tip $(\sim 625 \mu \mathrm{m})$ - was slightly less oxidized than the middle section, with $\mathrm{Fe}(\mathrm{III}) /$ $\mathrm{Fe}_{\text {total }}$ ratios between 0.25 and 0.5 . For hypha $\mathrm{B}$ and $\mathrm{C}$, the trends of $\mathrm{Fe}(\mathrm{II})$ oxidation were different with the biotite beneath the tip being generally more oxidized than under the older sections of the hypha (Figure 2A and B). When considering the $\mathrm{Fe}(\mathrm{III}) / \mathrm{Fe}_{\text {total }}$ depth profiles (Figure 2), there is also a large variability from one FIB section to another regardless if the measurements were carried out on the same or on different biotite flakes. For example, TIP, TIP +2 , and TIP +3 of hypha $\mathrm{C}$ and TIP of hypha $\mathrm{B}$ did not show variations with depth, while other sections (TIP +2 for hypha A, TIP +1 and TIP +2 for hypha B, and TIP +1 for hypha C) showed an increase in the $\mathrm{Fe}(\mathrm{III}) / \mathrm{Fe}_{\text {total }}$ ratios toward the interface with the hypha (Figure 2). On the contrary, two sections in hypha $\mathrm{A}$ (TIP +1 and, to a lesser extent, TIP) showed a decrease in $\mathrm{Fe}(\mathrm{III}) / \mathrm{Fe}_{\text {total }}$ ratios toward the interfacial regions compared to deeper portion of the sections.

We interpret these discrepancies in the extent of $\mathrm{Fe}$ (II) oxidation to be the consequence of either differences in exposure time between the mineral and the hypha or in temporal variations in the biological activity of each hypha. It is worth noting that the tip of a hypha and, naturally its most proximal region, are the most active both physiologically, ${ }^{39}$ and in terms of excretion. ${ }^{40}$ Thus, these would be putatively the most "active $\mathrm{Fe}(\mathrm{II})$ oxidizing" portion of the hypha. Apical growth of hypha proceeds by sudden pulses irregularly spread in time and thus growth is far from continuous. ${ }^{41}$ This means that at any given point during the colonization of the biotite surface, the period of interaction between the tip and the biotite surface (i.e., the time period when $\mathrm{Fe}$ (II) oxidation occurs) can vary greatly. Thus, the $\mathrm{Fe}(\mathrm{III}) / \mathrm{Fe}_{\text {total }}$ ratios in biotite do not necessarily increase from the tip along the hypha. The depth profile of $\mathrm{Fe}(\mathrm{III}) / \mathrm{Fe}_{\text {total }}$ in section TIP $+1 \mathrm{~B}$ (Figure $2 \mathrm{~B}$ ) shows an increase from the structural value of $\sim 0.2$ at $\sim 600 \mathrm{~nm}$ to a maximum of $\sim 0.8$ at the hypha-mineral interface. This suggests that the $\mathrm{Fe}(\mathrm{II})$ oxidation process is mediated from the interface with the hypha. Previous studies have already shown that the interfacial electron transfer from reduced dissolved cations-such as $\mathrm{Fe}$ (II) - to micas and clay mineral surfaces occur readily and are fast. ${ }^{42-44}$ The electron hopping rate or the conductivity along octahedral sheets (i.e., parallel to (001) plane) are fast in annite $\left(10^{6} \mathrm{~s}^{-1}\right)^{45}$ and nontronite $\left(10^{-5}\right.$ $\left.\mathrm{s}^{-1}\right) .{ }^{46}$ In the latter, an electron would travel $0.5 \mu \mathrm{m}$ in only 4 min along an octahedral sheet; ${ }^{46}$ however electron transfer through tetrahedral sheets or across interfoliar space (perpendicular to (001) plane) is much slower. For the Moen biotite (used in the present study), Rüscher and Gall ${ }^{47}$ report electrical conductivities $(\sigma)$ perpendicular to $(001)$ plane 3 orders of magnitude slower than parallel to (001) plane, nevertheless the former was still measured to be $\sim 10^{-13} \mathrm{~S} \cdot \mathrm{cm}^{-1}$. The same authors suggest that the conductivity perpendicular to (001) plane is controlled by defects in the biotite lattice structure that create conducting bridges between $\mathrm{T}-\mathrm{O}-\mathrm{T}$ (tetrahedral-octahedral-tetrahedral) layers. In Figure 3D and also in the work of Bonneville et al. ${ }^{27}$ (in Figure 3), numerous microcracks and defects are visible to a depth of $\sim 300 \mathrm{~nm}$ (and possibly deeper) in the biotite lattice structure beneath hypha, we hypothesize that these defects facilitate the "upward" electron transfer and explain that substantial $\mathrm{Fe}$ (II) oxidation could affect "deep" portions of the biotite structure in the time frame of the hyphal colonization.

A recent AFM study showed that $P$. involutus tips colonizing chlorite [001] basal plane grow on a $40-80 \mathrm{~nm}$ thick layer of 
hydrated extracellular polymeric substances, ${ }^{48}$ which are also visible in sections in Figure 3C (arrows) and Figure S-3. We suggest this "biolayer" to be the location of the oxidative compounds at the surface of the biotite. This is not surprising because our fungi species, $P$. involutus, can secrete or express genes coding for various organic compounds susceptible to oxidize $\mathrm{Fe}(\mathrm{II})$ such as laccase ${ }^{49}$ and hydroxymate-bearing compounds. ${ }^{50}$ Furthermore, during respiration, reactive oxygen species (ROS i.e., $\mathrm{O}_{2}^{-}, \mathrm{H}_{2} \mathrm{O}_{2}$, and $\mathrm{OH}^{\bullet}$ ) can easily be formed by the interaction of $\mathrm{O}_{2}$ with common cellular constituents like flavoproteins and quinones. ${ }^{51}$ In most cases, ROS are quickly degraded back to $\mathrm{O}_{2}$ by dismutase and catalase. However, when excreted, ROS can have a profound effect on redox sensitive elements in the hypha near-environment. For instance, Stilbella aciculosa (Ascomycete) is known to excrete $\mathrm{O}_{2}^{-}$that oxidizes dissolved $\mathrm{Mn}(\mathrm{II})$ leading to the precipitation of $\mathrm{Mn}(\mathrm{IV})$ oxide. ${ }^{52}$ A recent study by Keiluweit and co-workers ${ }^{53}$ further demonstrates that the $\mathrm{Mn}$ (II) oxidative capability of fungi is key to the long-term organic matter degradation in soils.

In the current study, we complemented the iron speciation measurements with $\mu$-XANES measurements at the $\mathrm{C}$ 1s edge to detect organic compounds potentially present within the biotite or at the biotite-hypha interface (Figure 4). To visualize this biotite-hypha boundary, the $\mathrm{K}$ maps of the hypha $\mathrm{A}$ sections are useful (Figure 4, maps at right). For hypha $B$ and $\mathrm{C}$, the $\mathrm{Fe}$ peak area integrations were used to pinpoint the hypha-biotite interface in lines-cans (as illustrated in Figure S2 for the control section sampled close to hypha A). In our previous study, ${ }^{5}$ we showed that $\mathrm{Fe}$ and $\mathrm{K}$ removal from biotite at the interface with hypha were only effective in the topmost $40 \mathrm{~nm}$ of the biotite in direct contact with the hypha. This is however also about the spatial resolution of the STXM rastering images/lines-cans. Therefore, the interface between the $\mathrm{Fe} / \mathrm{K}$-rich biotite and the K-"depleted" fungi appears here much less sharp $(\sim 150-200 \mathrm{~nm}$ in thickness i.e. the equivalent of 3-4 pixels, Figures 2 and 4). In addition, the biotite [001] basal planes were probably not exactly parallel to the incident $\mathrm{X}$-ray beam, and thus, this misalignment effectively enlarged the visualization of the physical hypha-biotite interface. The $\mathrm{C}=\mathrm{C}-$ maps (Figure 4 at left) show the opposite pattern to $\mathrm{K}$, with no signals in the biotite and high levels in the fungi. Note that the Pt layer deposited on top of the fungi during the FIB sectioning $(\sim 1.5 \mu \mathrm{m}$ thick, see also Figure $2 \mathrm{~A})$ contains some $\mathrm{O}$ and is rich in $\mathrm{C}$, originating from the precursor gas $\left(\mathrm{C}_{5} \mathrm{H}_{5} \mathrm{Pt}\left(\mathrm{CH}_{3}\right)_{3}\right)$ used for the Pt deposition process. ${ }^{54}$ The Pt deposit makes a clear distinction of the hypha very difficult in our chemical maps-however based on the process SEM images taken during the FIB sectioning (not shown but see Figure 1B), the hypha on top of biotite were about $250 \mathrm{~nm}$ thick and thus this value was transferred also to the chemical maps reported in Figures 2 and 4. The $-\mathrm{COOH}$ maps show a weak to moderate signal in the biotite portions of the three FIB sections of hypha A (Figure 4). At first, we interpreted this $-\mathrm{COOH}$ signal within biotite to be due to electron/ion beam induced deposition (E/IBID) during FIB sectioning. ${ }^{55}$ However, the amorphous carbon (graphite $\mathrm{C}$ ) resulting from E/IBID would have given a signal of $\mathrm{sp}^{2}$ hybridized carbon map, which was not the case. This leaves open the possibility of $-\mathrm{COOH}$ containing compounds to be present within the biotite as a result of hypha colonization. Further research is needed to characterize in situ the composition of this hyphal "biolayer" and its potential role in the fungal weathering process.

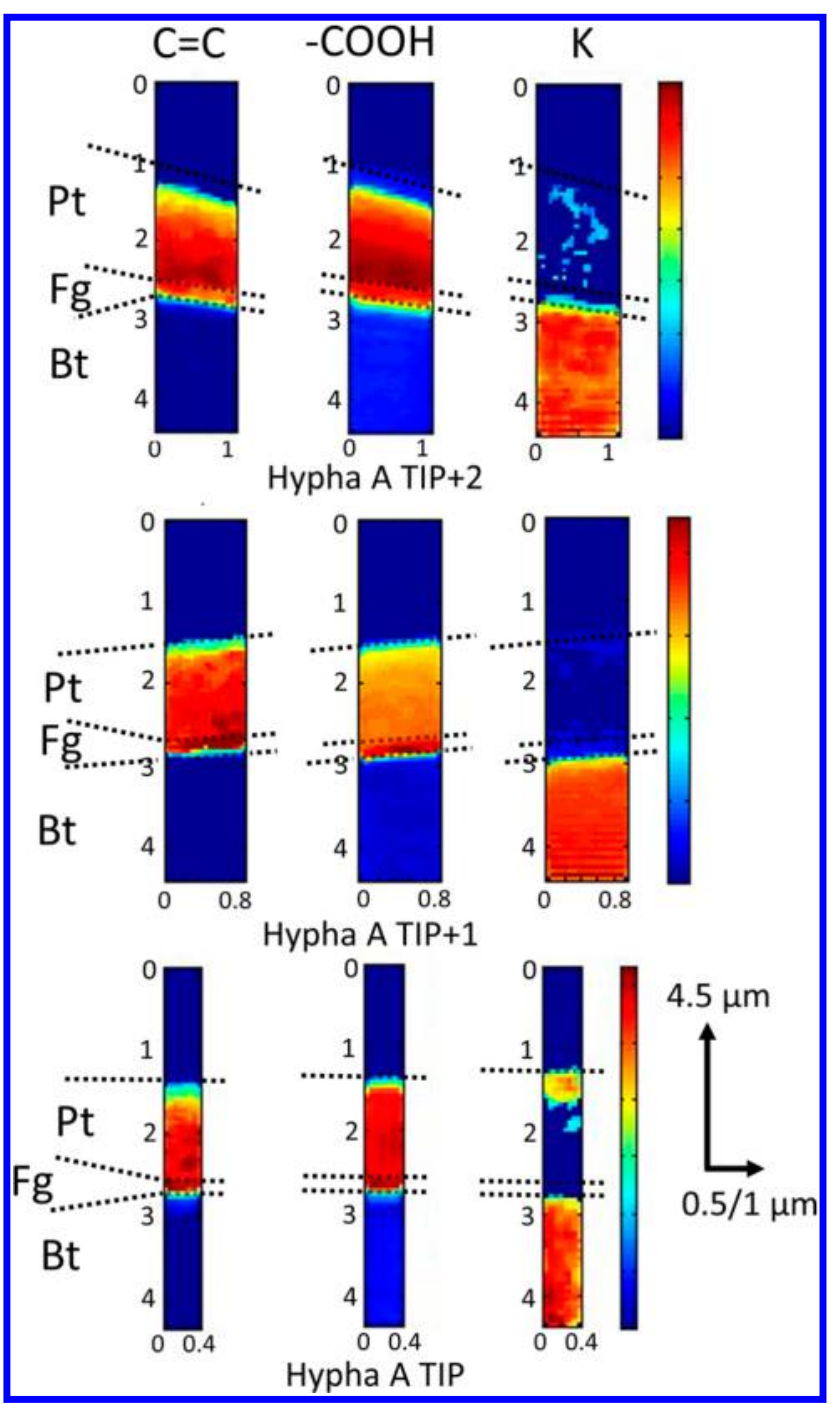

Figure 4. Abundance maps of $\mathrm{sp}^{2}$ hydribized carbon $(-\mathrm{C}=\mathrm{C}-$ ), carboxyl carbon, and potassium in three FIB sections along hypha A. Maps were calculated from peaks integration (see Figure S-1). Numbers on axis are length and width in $\mu \mathrm{m}$ of the area analyzed.

The implications of this large biotite Fe(II) oxidation are far reaching in terms of fungal weathering. Structural $\mathrm{Fe}$ (II) oxidation triggers (i) the loss of the $\mathrm{Fe}$ (III) from the octahedral sheets concomitant with the conversion of coordinating hydroxyl into oxide groups, and as a result (ii) the formation of amorphous $\mathrm{Fe}$ (III) oxides in the interlayer space. ${ }^{18,27,56-58}$ The growth of $\mathrm{Fe}$ (III) oxide subdomains in biotite imply a local increase in volume inducing strain in the biotite lattice. ${ }^{29,30}$ Structural defects in biotite lattices resulting from $\mathrm{Fe}$ (II) oxidation alone have been also suggested. ${ }^{59}$ Furthermore, according to Fletcher et al., ${ }^{30}$ as biotite $\mathrm{Fe}(\mathrm{II})$ oxidation proceeds and ferrihydrite is formed, elastic energy strain (per unit surface) accumulates until it reaches values equivalent to the surface energy of fracture $(2 \Gamma-$ Table S2). Once this value is reached, a crack forms. Interestingly, we showed previously, ${ }^{27}$ based on HR-TEM micrographs of FIB section across similar hyphae-biotite interfaces, that the fungal colonization leads to a substantial diffraction contrast (biotite crystal structure close to the interface was misorientated by a $14^{\circ}$ angle relative to bulk biotite) as well as numerous microcracks resulting from a mechanical forcing of the biotite lattices. In some instances, 
rupture of the $\mathrm{T}-\mathrm{O}-\mathrm{T}[001]$ biotite planes were associated with subdomains of ferrihydrite (Figure 3D in ref 27). Such microcracks and diffraction contrasts were also observed in the FIB sections described in the current study (e.g., Figure 3D and Figure S3). Using Fletcher's approach ${ }^{30}$ (See the Supporting Information for calculation), we tested whether the elastic energy strain due to $\mathrm{Fe}(\mathrm{III})$ hydroxide formation in biotite could trigger crack formation. Fletcher et al. ${ }^{30}$ assumed that all of the oxidized $\mathrm{Fe}$ (II) would form $\mathrm{Fe}$ (III) hydroxides within the biotite. This is questionable because Rancourt et al. ${ }^{57}$ showed (for annite) that $\mathrm{Fe}$ (III) hydroxides started to form only once the $\mathrm{Fe}(\mathrm{III}) / \mathrm{Fe}_{\text {total }}$ ratio reached a value of $\sim 0.66$ and that $\mathrm{Fe}(\mathrm{III})$ hydroxides represented at maximum $11 \%$ of the total $\mathrm{Fe}$ in the phase. Using the $11 \%$ as a maximum value, we calculated the threshold $(2 \Gamma)$ required for crack formation within the top $\sim 30 \mathrm{~nm}$ of the oxidized biotite-hyphae interface. In other words, when the $\mathrm{Fe}(\mathrm{III}) / \mathrm{Fe}_{\text {total }}$ exceeded the ratio of $\sim 0.66$ and ferrihydrite made up $11 \%$ of the $\mathrm{Fe}_{\text {total }}$ in the biotite structure, the formation of microcracks at $\sim 30 \mathrm{~nm}$ intervals was feasible within an oxidation front progressing deeper into the biotite. The calculated values are consistent with our observation of microcracks at depth within the biotite, yet such microcracks were not systematically distributed or present in all FIB sections possibly due to insufficient $\mathrm{Fe}$ (II) oxidation and $\mathrm{Fe}(\mathrm{III})$ hydroxides formation (Figure 3D and Figure S3). Nevertheless, when present, these microcracks were not isolated and appeared in large numbers even at depth corresponding to areas where large $\mathrm{Fe}$ (II) oxidation could still occur up to $200-300 \mathrm{~nm}$ from the interface with hypha (Figure S-3). Although difficult to quantify, the formation of such network of crack parallel to the [001] planes beneath the hypha and the secreted biolayer resulting from extensive $\mathrm{Fe}$ (II) oxidation will likely weaken the overall cohesion of the biotite and favor the exfoliation process (Figure $3 \mathrm{C}$ and D). We also hypothesize that such crack networks, when present, participate in the formation of channels beneath hypha once the colonization of the biotite surface occurred (see in Figure S-4 and ref 14). Similar surface features were reported as well in fungal weathering experiments with chlorite ${ }^{6}$ and on muscovite in field conditions. ${ }^{60}$ Alternatively, the formation of a crack network could facilitate the penetration of hypha within preexisting fracture of the biotite surface (Figure 5).

Although caution is required in extrapolating the results from our monoaxenic microcosms (free of bacteria) to natural settings, the ability of common mycorrhiza to oxidize large amounts of $\mathrm{Fe}$ (II) within the structure of biotite suggests that fungi could play an important role in Fe-phyllosilicate redox cycling in soils. Indeed, Fe-phyllosilicates can serve both as electron donors for $\mathrm{Fe}(\mathrm{II})$-oxidizing microbial communities hence producing oxy-biotite or $\mathrm{Fe}$ (III) oxides $^{22}$ and later as electron acceptors during dissimilatory $\mathrm{Fe}(\mathrm{III})$ reduction when anaerobic conditions may develop in soils. ${ }^{24}$ In contrast to microbial biotite $\mathrm{Fe}$ (II) oxidation, which forms limited amounts of $\mathrm{Fe}(\mathrm{III})$ and which is coupled to $\mathrm{NO}_{3}{ }^{-}$reduction, ${ }^{22}$ the extent of mycorrhizal $\mathrm{Fe}$ (II) oxidation in biotite is much larger (Fe(III) $/ \mathrm{Fe}_{\text {total }}$ up to 0.8 ) and is fuelled (through mycelia growth) by the photosynthetic activity of the host plants. More detailed studies on the coupling of mycorrhizal and microbial processes in relation to phyllosilicate $\mathrm{Fe}$ redox cycling and weathering are required to evaluate the significance of this phenomenon.

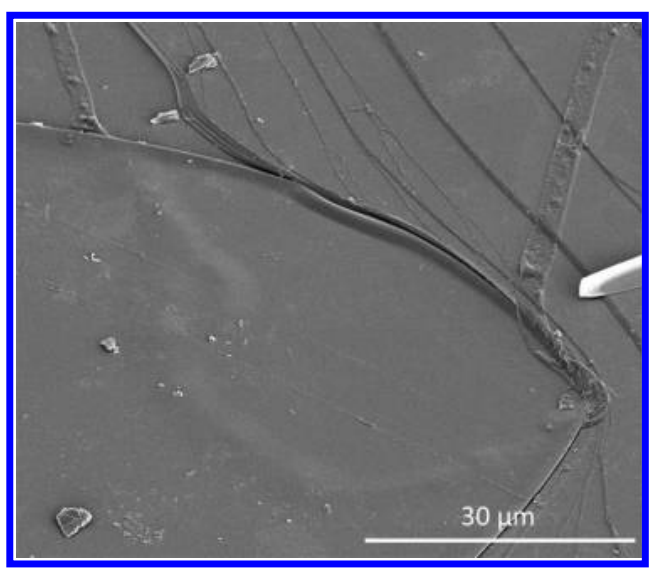

Figure 5. SEM micrograph of a hypha that penetrated a pre-existing fracture on the biotite surface (top left and bottom right of the picture). This hypha has grown under the topmost layer of biotite as evidenced by the bulged aspect of the surface showing the probable pathway of the hypha within biotite.

\section{ASSOCIATED CONTENT}

\section{S Supporting Information}

The Supporting Information is available free of charge on the ACS Publications website at DOI: 10.1021/acs.est.5b06178.

Include distances from tip of each FIB section sampled (Table S1), a description of the "biotite oxidation and ferrihydrite formation reactions scheme", as well as the details of "calculation of cracks calculation" with associated parameters (Table S2) (PDF)

\section{AUTHOR INFORMATION}

\section{Corresponding Author}

*E-mail: steeve.bonneville@ulb.ac.be (S.B.).

\section{Author Contributions}

All authors conceived the project and designed the study. S.B. carried out most of the data analysis and interpretation and wrote the manuscript.

\section{Notes}

The authors declare no competing financial interest.

\section{ACKNOWLEDGMENTS}

D. Kylcoyne from the beamline 5.3.2 at Advanced Light Source (Lawrence Berkeley National Laboratory) is acknowledged for help during STXM measurements. The Advanced Light Source is supported by the Director, Office of Science, Office of Basic Energy Sciences, of the U.S. Department of Energy under Contract No. DE-AC02-05CH11231. We acknowledge also the Paul Scherrer Institute, Villigen, Switzerland, for provision of synchrotron radiation beamtime at beamline PolLUX of the Swiss Light Source and would like to thank J. Raabe for assistance during STXM measurements. The authors thank John Harrington and Andy Brown and the Leeds Electron Microscopy and Spectroscopy Centre for help with the FIB sampling. A. Duran, M. Smits, and J. Leake from the Department of Animal and Plant Sciences at the U. of Sheffield are acknowledged for their help during the microcosm experiments. S.B. thanks R. Behrends (GFZ Potsdam) for helpful discussions during the preparation of the manuscript. Funding from the UK Natural Environment Research Council "Weathering Science Consortium" grant NE/C004566/1 and a regular grant NE/J022365/1 to L.G.B. are acknowledged. S.B. 
benefited also from the support of the "Victor Brien", "Van Buren" funds and the Fonds National de la Recherche Scientifique (FNRS-PDR T.1012.14).

\section{REFERENCES}

(1) Gadd, G. M. Geomycology: biogeochemical transformations of rocks, minerals, metals and radionuclides by fungi, bioweathering and bioremediation. Mvcol. Res. 2007, 111 (1), 3-49.

(2) Wang, B.; Qiu, Y.-L. Phylogenetic distribution and evolution of mycorrhizas in land plants. Mvcorrhiza 2006, 16 (5), 299-363.

(3) Smith, S. E.; Read, D. J. Mycorrhizal Symbiosis; Academic Press; Oxford, UK, 2008.

(4) Leake, J.; Johnson, D.; Donnelly, D.; Muckle, G.; Boddy, L.; Read, D. Networks of power and influence: the role of mycorrhizal mycelium in controlling plant communities and agroecosystem functioning. Can. J. Bot. 2004, 82 (8), 1016-1045.

(5) Bonneville, S.; Morgan, D. J.; Schmalenberger, A.; Bray, A.; Brown, A.; Banwart, S. A.; Benning, L. G. Tree-mycorrhiza symbiosis accelerate mineral weathering: Evidences from nanometer-scale elemental fluxes at the hypha-mineral interface. Geochim. Cosmochim. Acta 2011, 75 (22), 6988-7005.

(6) Gazzè, S. A.; Saccone, L.; Vala Ragnarsdottir, K.; Smits, M. M.; Duran, A. L.; Leake, J. R.; Banwart, S. A.; McMaster, T. J. Nanoscale channels on ectomycorrhizal-colonized chlorite: Evidence for plantdriven fungal dissolution. L. Geophys. Res. Biogeosciences 2012, 117 (63), G00N09.

(7) Smits, M. M.; Bonneville, S.; Benning, L. G.; Banwart, S. A.; Leake, J. R. Plant-driven weathering of apatite - the role of an ectomycorrhizal fungus: Plant-driven fungal weathering of apatite. Geobiology 2012, 10 (5), 445-456.

(8) Schmalenberger, A.; Duran, A. L.; Bray, A. W.; Bridge, J.; Bonneville, S.; Benning, L. G.; Romero-Gonzalez, M. E.; Leake, J. R.; Banwart, S. A. Oxalate secretion by ectomycorrhizal Paxillus involutus is mineral-specific and controls calcium weathering from minerals. $\underline{\text { Sci. }}$ Rep. 2015, 5, 12187.

(9) Smits, M. M.; Johansson, L.; Wallander, H. Soil fungi appear to have a retarding rather than a stimulating role on soil apatite weathering. Plant Soil 2014, 385 (1-2), 217-228.

(10) Nesbitt, H. W.; Young, G. M. Prediction of some weathering trends of plutonic and volcanic rocks based on thermodynamic and kinetic considerations. Geochim. Cosmochim. Acta 1984, 48 (7), 15231534.

(11) Chae, G.-T.; Yun, S.-T.; Kwon, M.-J.; Kim, Y.-S.; Mayer, B. Batch dissolution of granite and biotite in water: Implication for fluorine geochemistry in groundwater. Geochem. I. 2006, 40 (1), 95102.

(12) Bray, A. W.; Oelkers, E. H.; Bonneville, S.; Wolff-Boenisch, D.; Potts, N. J.; Fones, G.; Benning, L. G. The effect of pH, grain size, and organic ligands on biotite weathering rates. Geochim. Cosmochim. Acta 2015, 164, 127-145.

(13) Hopf, J.; Langenhorst, F.; Pollok, K.; Merten, D.; Kothe, E. Influence of microorganisms on biotite dissolution: An experimental approach. Chem. Erde 2009, 69, 45-56.

(14) Balogh-Brunstad, Z.; Kent Keller, C.; Thomas Dickinson, J.; Stevens, F.; Li, C. Y.; Bormann, B. T. Biotite weathering and nutrient uptake by ectomycorrhizal fungus, Suillus tomentosus, in liquid-culture experiments. Geochim. Cosmochim. Acta 2008, 72 (11), 2601-2618.

(15) Wallander, H.; Wickman, T. Biotite and microcline as potassium sources in ectomycorrhizal and non-mycorrhizal Pinus sylvestris seedlings. Mycorrhiza 1999, 9 (1), 25-32.

(16) Malmström, M.; Banwart, S. Biotite dissolution at $25 \mathrm{C}$ : The $\mathrm{pH}$ dependence of dissolution rate and stoichiometry. Geochim. Cosmochim. Acta 1997, 61 (14), 2779-2799.

(17) Bray, A. W.; Benning, L. G.; Bonneville, S.; Oelkers, E. H. Biotite surface chemistry as a function of aqueous fluid composition. Geochim. Cosmochim. Acta 2014, 128, 58-70.
(18) Banfield, J. F.; Eggleton, R. A. Transmission electron microscope study of biotite weathering. Clavs Clav Miner. 1988, 36 (1), 47-60.

(19) Shen, J.; Tang, C.; Rengel, Z.; Zhang, F. Root-induced acidification and excess cation uptake by $\mathrm{N} 2$-fixing Lupinus albus grown in phosphorus-deficient soil. Plant Soil 2004, 260 (1-2), 6977.

(20) Leyval, C.; Berthelin, J. Interactions between Laccaria laccata, Agrobacterium radiobacter and beech roots: Influence on $\mathrm{P}, \mathrm{K}, \mathrm{Mg}$, and Fe mobilization from minerals and plant growth. Plant Soil 1989, 117 (1), 103-110.

(21) Barker, W. W.; Welch, S. A.; Chu, S.; Banfield, J. F. Experimental observations of the effects of bacteria on aluminosilicate weathering. Am. Mineral. 1998, 83, 1551-1563.

(22) Shelobolina, E.; Xu, H.; Konishi, H.; Kukkadapu, R.; Wu, T.; Blothe, M.; Roden, E. Microbial Lithotrophic Oxidation of Structural $\mathrm{Fe}(\mathrm{II})$ in Biotite. Appl. Environ. Microbiol. 2012, 78 (16), 5746-5752.

(23) Bonneville, S.; Behrends, T.; Van Cappellen, P. Solubility and dissimilatory reduction kinetics of iron(III) oxyhydroxides: A linear free energy relationship. Geochim. Cosmochim. Acta 2009, 73 (18), 5273-5282.

(24) Brookshaw, D. R.; Lloyd, J. R.; Vaughan, D. J.; Pattrick, R. A. D. Bioreduction of biotite and chlorite by a Shewanella species. Am. Mineral. 2014, 99 (8-9), 1746-1754.

(25) Ottow, J. C. G.; Von Klopotek, A. Enzymatic reduction of iron oxide by fungi. Appl. Microbiol. 1969, 18 (1), 41-43.

(26) Arocena, J. M.; Velde, B.; Robertson, S. J. Weathering of biotite in the presence of arbuscular mycorrhizae in selected agricultural crops. Appl. Clav Sci. 2012, 64, 12-17.

(27) Bonneville, S.; Smits, M. M.; Brown, A.; Harrington, J.; Leake, J. R.; Brydson, R.; Benning, L. G. Plant-driven fungal weathering: Early stages of mineral alteration at the nanometer scale. Geology 2009, 37 (7), 615-618.

(28) Smits, M. M.; Herrmann, A. M.; Duane, M.; Duckworth, O. W.; Bonneville, S.; Benning, L. G.; Lundström, U. The fungal-mineral interface: challenges and considerations of micro-analytical developments. Fungal Biol. Rev. 2009, 23 (4), 122-131.

(29) Behrens, R.; Bouchez, J.; Schuessler, J. A.; Dultz, S.; Hewawasam, T.; Von Blanckenburg, F. Mineralogical transformations set slow weathering rates in low-porosity metamorphic bedrock on mountain slopes in a tropical climate. Chem. Geol. 2015, 411, 283298

(30) Fletcher, R.; Buss, H.; Brantley, S. A spheroidal weathering model coupling porewater chemistry to soil thicknesses during steadystate denudation. Earth Planet. Sci. Lett. 2006, 244 (1-2), 444-457.

(31) Jamtveit, B.; Putnis, C. V.; Malthe-Sørenssen, A. Reaction induced fracturing during replacement processes. Contrib. Mineral. Petrol. 2009, 157 (1), 127-133.

(32) Smits, M. M.; Bonneville, S.; Haward, S.; Leake, J. R. Ectomycorrhizal weathering, a matter of scale? Mineral. Mag. 2008, 72 (1), 131-134.

(33) Moffet, R. C.; Henn, T.; Laskin, A.; Gilles, M. K. Automated Chemical Analysis of Internally Mixed Aerosol Particles Using X-ray Spectromicroscopy at the Carbon K-Edge ${ }^{\dagger}$. Anal. Chem. 2010, 82 (19), 7906-7914.

(34) Keiluweit, M.; Bougoure, J. J.; Zeglin, L. H.; Myrold, D. D.; Weber, P. K.; Pett-Ridge, J.; Kleber, M.; Nico, P. S. Nano-scale investigation of the association of microbial nitrogen residues with iron (hydr)oxides in a forest soil O-horizon. Geochim. Cosmochim. Acta 2012, 95, 213-226.

(35) http://www.mathworks.com/matlabcentral/fileexchange/ 24006-stxm-data-analysis-script-collection-stacklab (accessed 11/05/ 2016).

(36) http://www.mathworks.com/matlabcentral/fileexchange/ 29085-stxm-spectromicroscopy-particle-analysis-routines (accessed $11 / 05 / 2016)$

(37) Bourdelle, F.; Benzerara, K.; Beyssac, O.; Cosmidis, J.; Neuville, D. R.; Brown, G. E.; Paineau, E. Quantification of the ferric/ferrous 
iron ratio in silicates by scanning transmission X-ray microscopy at the Fe L2,3 edges. Contrib. Mineral. Petrol. 2013, 166 (2), 423-434.

(38) Ferrow, E. A. Experimental weathering of biotite, muscovite and vermiculite a Mössbauer spectroscopy study. Eur. J. Mineral. 2002, 14 (1), 85-95.

(39) Deacon, J. Fungal Biology, 4th ed.; Blackwell Publishing, 2013.

(40) Bartnicki-Garcia, S.; Bracker, C. E.; Gierz, G.; López-Franco, R.; $\mathrm{Lu}, \mathrm{H}$. Mapping the growth of fungal hyphae: orthogonal cell wall expansion during tip growth and the role of turgor. Biophys. J. 2000, 79 (5), 2382.

(41) Lopez-Franco, R.; Bartnicki-Garcia, S.; Bracker, C. E. Pulsed growth of fungal hyphal tips. Proc. Natl. Acad. Sci. U. S. A. 1994, 91 (25), 12228-12232.

(42) Alexandrov, V.; Neumann, A.; Scherer, M. M.; Rosso, K. M. Electron exchange and conduction in nontronite from first-principles. J. Phys. Chem. C 2013, 117 (5), 2032-2040.

(43) Neumann, A.; Olson, T. L.; Scherer, M. M. Spectroscopic evidence for $\mathrm{Fe}(\mathrm{II})-\mathrm{Fe}(\mathrm{III})$ electron transfer at clay mineral edge and basal sites. Environ. Sci. Technol. 2013, 47 (13), 6969-6977.

(44) Schaefer, M. V.; Gorski, C. A.; Scherer, M. M. Spectroscopic evidence for interfacial $\mathrm{Fe}(\mathrm{II})-\mathrm{Fe}(\mathrm{III})$ electron transfer in a clay mineral. Environ. Sci. Technol. 2011, 45 (2), 540-545.

(45) Rosso, K. M.; Ilton, E. S. Charge transport in micas: The kinetics of FeII/III electron transfer in the octahedral sheet. J. Chem. Phys. 2003, 119 (17), 9207-9218.

(46) Neumann, A.; Wu, L.; Li, W.; Beard, B. L.; Johnson, C. M.; Rosso, K. M.; Frierdich, A. J.; Scherer, M. M. Atom Exchange between Aqueous $\mathrm{Fe}(\mathrm{II})$ and Structural $\mathrm{Fe}$ in Clay Minerals. Environ. Sci. Technol. 2015, 49 (5), 2786-2795.

(47) Rüscher, C. H.; Gall, S. On the polaron-mechanism in ironbearing trioctahedral phyllosilicates: an investigation of the electrical and optical properties. Phys. Chem. Miner. 1995, 22 (7), 468-478.

(48) Gazzè, S. A.; Saccone, L.; Smits, M. M.; Duran, A. L.; Leake, J. R.; Banwart, S. A.; Ragnarsdottir, K. V.; McMaster, T. J. Nanoscale Observations of Extracellular Polymeric Substances Deposition on Phyllosilicates by an Ectomycorrhizal Fungus. Geomicrobiol. J. 2013, 30 (8), 721-730.

(49) Jacob, C.; Courbot, M.; Martin, F.; Brun, A.; Chalot, M. Transcriptomic responses to cadmium in the ectomycorrhizal fungus Paxillus involutus. FEBS Lett. 2004, 576 (3), 423-427.

(50) Haselwandter, K.; Bobleter, O.; Read, D. J. Degradation of ${ }^{14} \mathrm{C}$ labelled lignin and dehydropolymer of coniferyl alcohol by ericoid and ectomycorrhizal fungi. Arch. Microbiol. 1990, 153 (4), 352-354.

(51) Aguirre, J.; Ríos-Momberg, M.; Hewitt, D.; Hansberg, W. Reactive oxygen species and development in microbial eukaryotes. Trends Microbiol. 2005, 13 (3), 111-118.

(52) Hansel, C. M.; Zeiner, C. A.; Santelli, C. M.; Webb, S. M. $\mathrm{Mn}$ (II) oxidation by an ascomycete fungus is linked to superoxide production during asexual reproduction. Proc. Natl. Acad. Sci. U. S. A. 2012, 109 (31), 12621-12625.

(53) Keiluweit, M.; Nico, P.; Harmon, M. E.; Mao, J.; Pett-Ridge, J.; Kleber, M. Long-term litter decomposition controlled by manganese redox cycling. Proc. Natl. Acad. Sci. U. S. A. 2015, 112 (38), E5253E5260.

(54) Vaz, A. R.; da Silva, M. M.; Leon, J.; Moshkalev, S. A.; Swart, J. W. Platinum thin films deposited on silicon oxide by focused ion beam: characterization and application. J. Mater. Sci. 2008, 43 (10), 3429-3434.

(55) Randolph, S. J.; Fowlkes, J. D.; Rack, P. D. Focused, Nanoscale Electron-Beam-Induced Deposition and Etching. Crit. Rev. Solid State Mater. Sci. 2006, 31 (3), 55-89.

(56) Farmer, V. C.; Russell, J. D.; McHardy, W. J.; Newman, A. C. D.; Ahlrichs, J. L.; Rimsaite, J. Y. H. Evidence for loss of protons and octahedral iron from oxidized biotites and vermiculites. Mineral. Mag. 1971, 38, 121.

(57) Rancourt, D. G.; Mercier, P. H. J.; Cherniak, D. J.; Desgreniers, S.; Kodama, H.; Robert, J.-L.; Murad, E. Mechanisms and crystal chemistry of oxidation in annite: Resolving the hydrogen-loss and vacancy reactions. Clays Clay Miner. 2001, 49 (6), 455-491.
(58) Murakami, T.; Utsunomiya, S.; Yokoyama, T.; Kasama, T. Biotite dissolution processes and mechanisms in the laboratory and in nature: Early stage weathering environment and vermiculitization. Am. Mineral. 2003, 88 (2-3), 377-386.

(59) Kogure, T.; Nespolo, M. Atomic structures of planar defects in oxybiotite. Am. Mineral. 2001, 86 (3), 336-340.

(60) Quirk, J.; Leake, J. R.; Banwart, S. A.; Taylor, L. L.; Beerling, D. J. Weathering by tree-root-associating fungi diminishes under simulated Cenozoic atmospheric $\mathrm{CO}_{2}$ decline. Biogeosciences 2014, 11 (2), 321-331. 